Volume 10 Issue 2, April-June 2016: pp. 221-412. Copyright (c) 2015-2016 FIAT JUSTISIA. Faculty of Law, Lampung University, Bandarlampung, Lampung, Indonesia.

ISSN: 1978-5186 | e-ISSN: 2477-6238.

Open Access: http://jurnal.fh.unila.ac.id/index.php/fiat

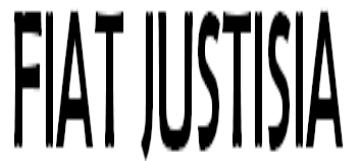

Fiat Justisia is licensed under a Creative Commons Attribution 4.0 International License, which permits unrestricted use, distribution, and reproduction in any medium, provided the original work is properly cited.

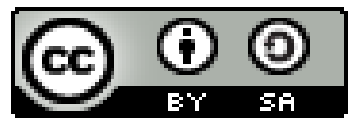

\title{
KEWENANGAN PT. PELABUHAN INDONESIA II (PERSERO) CABANG PANJANG DALAM PENGELOLAAN LAHAN KEPELABUHANAN (Studi Pemisahan Regulator dan Operator Pelabuhan)
}

\author{
The Authority PT. Pelabuhan Indonesia II (Persero) Subdivision \\ Panjang in Land Ports Management \\ (Study of Separation Regulator Port and Operator Port)
}

\author{
Aditiawan Muslim \\ PT. Pelabuhan Indonesia II (Persero) Cabang Panjang, Bandar Lampung \\ email : aditiawanmuslim@yahoo.com
}

\begin{abstract}
The authority PT. Pelabuhan Indonesia II (Persero) Subdivision Panjang in land management Ports after enactment Law Number 17 of 2008 on Shipping have experienced changes. Where the scope of portland management includes the formulation of Port Master Plan, the provision of portland, port monitoring land use, and exploitation of the portland. The results showed that the scope of authority land management port is a portland concession. It relates to the status of PT. Pelabuhan Indonesia II (Persero) Subdivision Panjang as a Badan Usaha Pelabuhan (BUP) which has the function of a role as a port operator. As for the formulation of the Port Master Plan, the provision of portland, port monitoring land use under the authority of the Port Authority which has the function of a role as a regulator. In a land concession pass port, PT. Pelabuhan Indonesia II (Persero) Subdivision Panjang is not included in the Port Enterprises whose business activities can run only after getting the concession of the port authority. Because granting concessions only to Port Business Entities are new. In addition, in article 344 paragraphs (2) of Law Number 17 of 2008 on Shipping provides legal certainty on the legal status of SOEs Ports presence in the business activities of port services.
\end{abstract}

Keywords: Authority, the Port Authority, PT. Pelabuhan Indonesia II (Persero) Subdivision Panjang 


\begin{abstract}
Abstrak
Kewenangan PT. Pelabuhan Indonesia II (Persero) Cabang Panjang di Pelabuhan pengelolaan lahan setelah berlakunya Undang-Undang Nomor 17 Tahun 2008 tentang Pelayaran telah mengalami perubahan. Di mana ruang lingkup manajemen portland meliputi perumusan Rencana Induk Pelabuhan, penyediaan portland, penggunaan lahan monitoring pelabuhan, dan eksploitasi portland. Hasil penelitian menunjukkan bahwa ruang lingkup manajemen port otoritas lahan konsesi portland. berkaitan dengan status PT. Pelabuhan Indonesia II (Persero) Cabang Panjang sebagai Badan Usaha Pelabuhan (BUP) yang memiliki fungsi peran sebagai operator pelabuhan. Adapun perumusan Rencana Induk Pelabuhan, penyediaan portland, penggunaan pemantauan lahan pelabuhan di bawah wewenang Otoritas Pelabuhan yang memiliki fungsi peran sebagai regulator. Dalam konsesi lahan lulus pelabuhan, PT. Pelabuhan Indonesia II (Persero) Cabang Panjang tidak termasuk di Pelabuhan Usaha yang kegiatan usahanya dapat berjalan hanya setelah mendapatkan konsesi dari otoritas pelabuhan. Karena pemberian konsesi hanya untuk Badan Usaha Pelabuhan (BUP) yang baru. Selain itu, dalam artikel 344 ayat (2) Undang-Undang Nomor 17 Tahun 2008 tentang Pelayaran memberikan kepastian hukum tentang status hukum kehadiran BUMN Pelabuhan dalam kegiatan usaha jasa pelabuhan.
\end{abstract}

Kata Kunci: Kewenangan, Kewenangan Pelabuhan, PT. Pelabuhan Indonesia II (Persero) Cabang Panjang

\title{
A. Pendahuluan
}

Indonesia merupakan negara kepulauan yang dua pertiga wilayahnya adalah perairan dan terletak pada posisi strategis, berada di alur strategis perdagangan dunia. Sebagai negara kepulauan, peran pelabuhan sangat vital dalam perekonomian Indonesia. Kehadiran pelabuhan yang memadai berperan besar dalam menunjang mobilitas barang. Pelabuhan menjadi sarana penting untuk menghubungkan antar pulau maupun antar negara dan pengembangan perekonomian wilayah.

Besarnya peran Pelabuhan di Indonesia tercermin dalam kegiatan pelabuhan untuk menunjang perdagangan internasional dan domestik secara nasional pada skala sangat besar. Serta ikut menunjang pertumbuhan industri dan perdagangan yang merupakan segmen usaha pelabuhan tersebut agar pengoperasiannya dapat dilakukan secara efektif, efisien, dan profesional sehingga pelayanan pelabuhan menjadi lancar, aman, dan cepat dengan biaya terjangkau. Pada dasarnya pelayanan yang diberikan oleh pelabuhan adalah pelayanan terhadap kapal, barang, dan penumpang.

PT. Pelabuhan Indonesia II (Persero) Cabang Panjang (Pelindo Panjang) merupakan salah satu pelabuhan yang berada di bawah pengelolaan 
manajemen PT. Pelabuhan Indonesia II (Persero), sebuah Badan Usaha Milik Negara yang bergerak di bidang jasa kepelabuhanan dan logistik nasional $^{1}$ yang merupakan roda penggerak perekonomian di Provinsi Lampung dimana sebagian besar produksi nya adalah dari hasil alam. Selain sebagai Badan Usaha Milik Negara (BUMN) yang berorientasi pada profit, Pelindo Panjang sesuai yang diamanatkan oleh Undang-Undang Nomor 17 Tahun 2008 tentang Pelayaran (UU 17/2008 Tentang Pelayaran) adalah sebagai Badan Usaha Pelabuhan (BUP) yang berperan sebagai Operator yang mengoperasikan terminal dan fasilitas pelabuhan lainya.

Sebelum lahirnya UU 17 / 2008 Tentang Pelayaran, Pelindo Panjang memiliki wewenang sebagai Regulator dan merangkap sebagai Operator di Pelabuhan. Sehingga dalam pengelolaan lahan Kepelabuhanan, Pelindo Panjang bertugas Sebagai pengelola. Artinya menyediakan lahan kepelabuhanan, mengawasi penggunaannya dan mengoperasikan sendiri lahan tersebut. Pemerintah memberikan kewenangan kepada Pelindo Panjang untuk mengelola lahan Kepelabuhanan sesuai dengan Surat Keputusan Bersama (SKB) Menteri Dalam Negeri dan Menteri Perhubungan Nomor 63 Tahun 1987 / KM 154 /AL 106 / PHB-87 Tanggal 23 Juli 1987 Tentang Batas - batas Daerah Lingkungan Kerja (DLKr) dan Daerah Lingkungan Kepentingan (DLKp) Pelabuhan Panjang. Dalam SKB tersebut, lahan yang diberikan seluas $\pm 81,8130$ Ha untuk DLKr dan $\pm 70,16$ Ha untuk DLKp.

Ditetapkan Rencana Induk Pelabuhan untuk Pelabuhan Panjang sesuai Keputusan Menteri Perhubungan Nomor 32 Tahun 2006 Tentang Rencana Induk Pelabuhan Panjang. Lahan Kepelabuhanan yang dilimpahkan kepada Pelindo Panjang diberikan Hak Pengelolaan (HPL) luas lahan $\pm 81,8130 \mathrm{Ha}$ untuk DLKr dan $\pm 70,16 \mathrm{Ha}$ untuk DLKp, Pelindo Panjang mengatur pemanfaatan areal (Land Use) sesuai fungsi pelabuhan baik dilihat dari segi operasional bongkar muat dan trafik dalam pelabuhan, maupun dalam aspek navigasi (Safety of Navigation) kapal ketika berada di daerah pelabuhan. Karena lahan adalah merupakan salah satu asset pelabuhan yang dikelola secara komersil. Untuk dapat dijadikan usaha komersil di DLKr Pelabuhan, maka pelabuhan tidak dapat berdiri sendiri yang tidak terlepas dari kegiatan lainnya ${ }^{2}$

Lahirnya UU 17 / 2008 Tentang Pelayaran, Pelindo Panjang hanya berperan sebagai Operator sedangkan Regulator adalah Otoritas Pelabuhan (OP). OP adalah lembaga pemerintah di pelabuhan sebagai otoritas yang melaksanakan fungsi pengaturan, pengendalian, dan pengawasan kegiatan kepelabuhanan yang diusahakan secara komersial. Dengan pemisahan

\footnotetext{
${ }^{1}$ Information Booklet PT. Pelabuhan Indonesia II (Persero) Cabang Panjang, 2015.

${ }^{2}$ Karsafman, Tjetjep. (2004). Port and Shipping. Jakarta, p. 16.
} 
Regulator dan Operator, Pelabuhan di Indonesia dapat mengarah pada Tatanan Kepelabuhanan Nasional yang baik.

Pemisahan peran Regulator dan Operator di Pelabuhan selain memberikan dampak positif seperti jelasnya kewenangan masing-masing pihak, terdapat juga dampak negatif. Beberapa polemik timbul dengan pemisahan peran tersebut. Selain terjadinya High Regulated (Terlalu birokratis) dalam penyelenggaraan kegiatan kepelabuhanan ${ }^{3}$. Pengelolaan lahan kepelabuhan terjadi tumpang tindih kewenangan. Pasal 83 ayat (1) huruf a UU 17/2008 Tentang Pelayaran jo. Pasal 42 ayat (2) Peraturan Pemerintah Nomor 61 Tahun 2009 Tentang Kepelabuhanan, Penyediaan lahan daratan dan perairan menjadi tugas dan tanggung jawab OP. Selanjutnya Pasal 344 ayat (3) UU 17/2008 Tentang Pelayaran, menyebutkan bahwa " Kegiatan pengusahaan di Pelabuhan yang telah diselanggarakan oleh Badan Usaha Milik Negara tetap diselenggarakan oleh Badan Usaha Milik Negara dimaksud". Penjelasan ayat tersebut :

Dimaksud dengan "tetap diselenggarakan oleh Badan Usaha Milik Negara" adalah Badan Usaha Milik Negara yang didirikan berdasarkan Peraturan Pemerintah Nomor 56 Tahun 1991, Peraturan Pemerintah Nomor 57 Tahun 1991, Peraturan Pemerintah Nomor 58 Tahun 1991, Peraturan Pemerintah Nomor 59 Tahun 1991, tetap menyelenggarakan kegiatan usaha pelabuhan yang meliputi :

1. Kegiatan yang diatur dalam Pasal 90 ayat (1), ayat (2), ayat (3), ayat (4) Undang-Undang ini.

2. Penyediaan kolam pelabuhan sesuai dengan peruntukkannya berdasarkan pelimpahan dari pemerintah dan ketentuan peraturan perundangundangan.

3. Pelayanan jasa pemanduan berdasarkan pelimpahan dari Pemerintah dan ketentuan peraturan perundang-undangan.

4. Penyediaan dan pengusahaan tanah sesuai kebutuhan berdasarkan pelimpahan dari pemerintah dan ketentuan perundang-undangan dibidang pertanahan.

Pelindo Panjang sebagai BUP bila dilihat dari Pasal 344 UU 17/2008 Tentang Pelayaran memiliki kewenangan dalam pengelolaan lahan kepelabuhan. Sama seperti kewenangan OP.

Pada dasarnya Status lahan/tanah baik itu daratan maupun perairan dalam Pelabuhan adalah Tanah yang dikuasai oleh negara yang mengandung arti sebagaimana dijelaskan dalam Pasal 2 ayat 2 UU No.5/1960 yaitu bahwa Negara mempunyai wewenang atas lahan/tanah tersebut untuk:

\footnotetext{
${ }^{3}$ Nuryanto. (2011). Implementasi Undang- Undang Pelayaran: Dapatkah Menghilangkan Monopoli Pelabuhan?. STIMART “AMNI”,
} 
1. Mengatur dan menyelenggarakan, peruntukan, penggunaan, persediaan dan pemeliharaan lahan tersebut.

2. Menentukan dan mengatur hubungan-hubungan hukum Antara orangorang dengan lahan tersebut.

3. Menentukan dan mengatur hubungan-hubungan hukum Antara orangorang dan perbuatan-perbuatan hukum mengenai lahan tersebut.

Adapun jika tanah Negara tersebut ingin digunakan oleh Pihak Ketiga maka hak penguasaan negara atas tanah tersebut wajib dikonversi menjadi Hak Pengelolaan dan Hak Pengelolaan berlangsung selama tanah tersebut dipergunakan untuk keperluan oleh instansi yang bersangkutan. Hal ini berarti jika pemegang Hak Pengelolaan atas tanah tersebut tidak lagi menjalankan urusannya, maka tanah tersebut akan kembali kepada Negara. Penyelenggara Pelabuhan sendiri diberikan hak untuk mengatur tanah tersebut.

Bila pengejawantahan amanat UU 17/2008 Tentang Pelayaran dilaksanakan, lahan HPL yang telah diberikan oleh Pelindo Panjang tidak dapat langsung dialihkan kepada OP. Namun harus melalui mekanisnya pelepasan hak kepada Negara, lalu diberikan kepada OP sebagai subjek HPL yang baru. Namun dengan mekanisme pelepasan hak pun belum dapat dilaksanakan. Padahal UU 17/2008 Tentang Pelayaran harus sudah berjalan paling lambat 3 tahun setelah diterbitkan UU tersebut. Dengan penjelasan dalam penentuan waktu 3 tahun adalah waktu yang cukup bagi Pemerintah merencanakan pengembangan pelabuhan dengan melakukan :

1. Evaluasi aset Badan Usaha Milik Negara yang menyelenggarakan usaha pelabuhan.

2. Audit secara menyeluruh terhadap aset Badan Usaha Milik Negara yang menyelenggarakan usaha pelabuhan.

Belum berjalannya UU 17 / 2008 Tentang Pelayaran khususnya dalam pengelolaan lahan kepelabuhanan yang ditelah diusahakan oleh Pelindo Panjang, menyebabkan beberapa masalah baru seperti belum jelasnya kewenangan pengelolaan lahan kepelabuhanan dimana OP dan Pelindo Panjang sebagai BUMN dan BUP yang masih eksis menguasai lahan tersebut. Sehingga tugas Regulator yang dijalankan OP dalam penyediaan lahan daratan dan perairan untuk kemudian di konsesi kan kepada BUP belum dapat dilaksanakan. Mengingat lahan yang ada saat masih dalam wewenang Pelindo Panjang yang saat ini hanya berperan sebagai BUP.

Berdasarkan latar belakang di atas, maka penulis tertarik menelaah pelaksanaan pengaturan pengelolaan lahan kepelabuhanan dalam peraturan perundang-undangan, dan kewenangan PT. Pelabuhan Indonesia II (Persero) Cabang Panjang dalam pengelolaan lahan Kepelabuhanan kaitannya dengan keberadaan Otoritas Pelabuhan sebagai operator. 
Penelitian ini menggunakan pendekatan yuridis normatif melalui data sekunder berupa bahan hukum primer dan sekunder yang diperoleh dari berbagai sumber yang berhubungan dengan permasalahan. Dianalisis secara kualitatif sehingga dapat dilakukan analisis dan dapat diperoleh jawaban permasalahan untuk ditarik kesimpulan dan saran.

\section{B. Pembahasan}

\section{Pelaksanaan Pengaturan Pengelolaan lahan kepelabuhanan dalam peraturan perundang-undangan}

"Bumi dan air dan kekayaan alam yang terkandung di dalamnya dikuasai oleh negara dan dipergunakan untuk sebesar-besarnya kemakmuran rakyat" Bunyi Undang-Undang Dasar Republik Indonesia 1945 Pasal 33 Ayat (3) tersebut merupakan landasan konstitusional bagi pembentukan Politik dan Hukum Tanah Nasional, yang berisi perintah kepada Negara agar bumi, air, dan kekayaan alam yang terkandung di dalamnya yang diletakkan dalam penguasaan Negara itu digunakan untuk mewujudkan sebesarbesarnya kemakmuran seluruh rakyat Indonesia.

Lahan Kepelabuhanan hakikatnya tanah milik negara dengan penguasaan terbatas/ tidak penuh. Artinya, terhadap tanah-tanah yang sudah dipunyai dengan suatu hak oleh suatu subyek hukum. Tanah ini dinamakan "tanah hak" atau "tanah yang dikuasai tidak langsung oleh Negara" . Kekuasaan Negara yang bersumber pada hak menguasai tanah oleh Negara terhadap tanah hak, dibatasi oleh isi dari hak itu. Artinya, kekuasan Negara tersebut dibatasi kekuasaan (wewenang) pemegang hak atas tanah yang diberikan oleh Negara untuk menggunakan haknya. Hal ini sesuai pada Pasal 2 ayat (3) UU 5/1960 Tentang Pokok-Pokok Dasar Agraria menetapkan :

(3) Wewenang yang bersumber pada hak menguasai dari Negara tersebut pada ayat 2 pasal ini digunakan untuk mencapai sebesar-besar kemakmuran rakyat dalam arti kebangsaan, kesejahteraan dan kemerdekaan dalam masyarakat dan Negara hukum Indonesia yang merdeka, berdaulat, adil dan makmur.

Pemegang hak atas tanah yang diberikan oleh Negara untuk mengelola suatu tanah diatur melalui Undang-Undang atau peraturan dibawahnya. Otoritas Pelabuhan diberikan Hak Pengelolaan sesuai pada Pasal 85 UU 17/2008 Tentang Pelayaran :

"Otoritas Pelabuhan dan Unit Penyelenggara Pelabuhan sebagaimana dimaksud dalam Pasal 81 ayat (1) diberi hak pengelolaan atas tanah dan pemanfaatan perairan sesuai dengan ketentuan peraturan perundang-undangan."

Lahan Kepelabuhanan adalah lahan yang diperuntukkan untuk kegiatan yang berkaitan dengan pelaksanaan fungsi pelabuhan untuk menunjang kelancaran, keamanan, dan ketertiban arus lalu lintas kapal, 
penumpang dan/atau barang, keselamatan dan keamanan berlayar, tempat perpindahan intra-dan/atau antarmoda serta mendorong perekonomian nasional dan daerah dengan tetap memperhatikan tata ruang wilayah.

Lahan Kepelabuhanan memiliki batas-batas wilayah sesuai dengan DLKp dan DLKr Pelabuhan. Untuk Pelabuhan Panjang DLKp dan DLKr ditetapkan sesuai Surat Keputusan Bersama Menteri Dalam Negeri dan Menteri Perhubungan Nomor Nomor 63 Tahun 1987 / KM 154 /AL 106 / PHB-87 Tanggal 23 Juli 1987 Tentang Batas - batas Daerah Lingkungan Kerja (DLKr) dan Daerah Lingkungan Kepentingan (DLKp) Pelabuhan Panjang. Dalam SKB tersebut, lahan yang ditetapkan seluas $\pm 81,8130 \mathrm{Ha}$ untuk DLKr dan $\pm 70,16 \mathrm{Ha}$ untuk DLKp. Dimana dengan terbitnya UU 17/2008 Tentang Pelayaran menjadi yugas dan wewenang Otoritas Pelabuhan dalam penyusunan DLKr dan DLKp.

Lingkup pengelolaan lahan Kepelabuhanan yang menjadi tugas dan wewenang Penyelenggara Pelabuhan dalam hal ini Otoritas Pelabuhan atau Unit Penyelenggara Pelabuhan berdasarkan UU No. 17/2008 Tentang Kepelabuhanan Jo. PP No. 61/2009 Tentang Kepelabuhan meliputi :

a. penyusunan Rencana Induk Pelabuhan serta Daerah Lingkungan Kerja dan Daerah Lingkungan Kepentingan pelabuhan.

b. Penyediaan lahan di daratan dan di perairan Pelabuhan.

c. Pengaturan dan Pengawasan penggunaan lahan daratan dan perairan pelabuhan.

d. Pengusahaan lahan Pelabuhan

\section{a. Menyusun Rencana Induk Pelabuhan serta Daerah Lingkungan Kerja dan Daerah Lingkungan Kepentingan pelabuhan.}

Rencana Induk Pelabuhan Panjang adalah pedoman pembangunan Pelabuhan Panjang yang mencakup keseluruhan kebutuhan dan penggunaan daratan serta perairan untuk kegiatan kepelabuhanan dan kegiatan penunjang pelabuhan dengan mempertimbangkan aspek-aspek teknis, pertahanan, keamanan, sosial budaya, serta aspek-aspek terkait lainnya.

Rencana Induk Pelabuhan merupakan instrumen perencanaan jangka panjang yang digunakan untuk pelabuhan baru dan pelabuhan eksis untuk rencana pengembangannya. ${ }^{4}$ Bagi pemerintah, pemilik modal swasta, keputusan penyediaan atau pembangunan sebuah pelabuhan perlu diawali dengan sebuah rencana yang sifatnya mengikat dalam jangka waktu investasi dari pelabuhan. Sehingga pelabuhan dapat mengantisipasi perkembangan trafik dan pengguna jasa pelabuhan ke depan, serta melakukan pengaturan

\footnotetext{
${ }^{4}$ Oloan SG., Raja dan Haryadi B, Eko. (2007). Manajemen Bisnis Pelabuhan. Jakarta: APE Publishing, p. 189.
} 
kembali dalam kaitannya dengan persaingan antar pelabuhan, dalam konteks jangka panjang. jadi rencana induk merupakan rasionalisasi dari tujuan dan arah jangka panjang pelabuhan yang dapat terukur oleh parameter-parameter teknis dan non teknis sehingga dampak duplikasi investasi, dan lemahnya daya dukung pelabuhan terhadap kelancaran arus barang dapat dihindari lewat penetapan Rencana Induk Pelabuhan yang sistematis. Bagi pemerintah daerah sekitar pelabuhan, Rencana Induk Pelabuhan merupakan referensi atau sebaliknya merupakan respon bagi pengembangan kawasan pesisir dalam bentuk tata ruang kawasan pesisir wilayah pelabuhan tersebut.

Maksud dan Tujuan penetapan Rencana Induk Pelabuhan meliputi : ${ }^{5}$

1) Sebagai pedoman dalam pengembangan dan pembangunan dan operasional kegiatan kepelabuhanan .

2) Sebagai alat pengendalian dan pengawasansegala kegiatan kepelabuhanan baik pembangunan, pengembangan dan operasioanal agar sesuai dengan rencana yang ditetapkan untuk kepentingan wilayah pelabuhan dan sekitarnya.

3) Sebagai alat pengatur kepelabuhan baik pembangunan, pengembangan dan operasional untuk saat kini maupun saat yang akan datang

4) Sebagai alat untuk mencapai tujuan/sasaran yang hendak dicapai dari fungsi dan peran pelabuhan di masa mendatang.

5) Menetapkan rencana penetapan fungsi kegiatan pokok dan penunjang pelabuhan jangka pendek, jangka menengah dan jangka penjang.

6) Menyusun rencana pembangunan dan pengembangan fasilitas dan utilitas pelabuhan pada lokasi yang dinilai memenuhi syarat.

7) Menyusun rencana pengelolaan lingkungan dan arahan jenis-jenis penanganan lingkungan.

8) Menyusun rencana pelaksanaan tahapan pembangunan dan pengembangan jangka pendek, jangka menengah dan jangka panjang

9) Menyusun rencana kebutuhan dan pemanfaatan baik ruang daratan (land use) dan perairan (water use).

Secara hierarki regulasi, Rencana Induk Pelabuhan harus mempertimbangkan aspek hukum perihal tata ruang yang lebih tinggi seperti tata ruang nasional dan struktur atau tatanan pengelolaan kepelabuhanan secara nasional, regional, dan lokal ${ }^{6}$

\footnotetext{
${ }^{5}$ Triatmojo, Bambang. (1996). Pelabuhan. Beta Offset, p. 74.

${ }^{6}$ Oloan SG., Raja dan Haryadi B, Eko. Op. Cit., p. 190.
} 


\section{Gambar 1. \\ Proses Persetujuan Rencana Induk Pelabuhan}

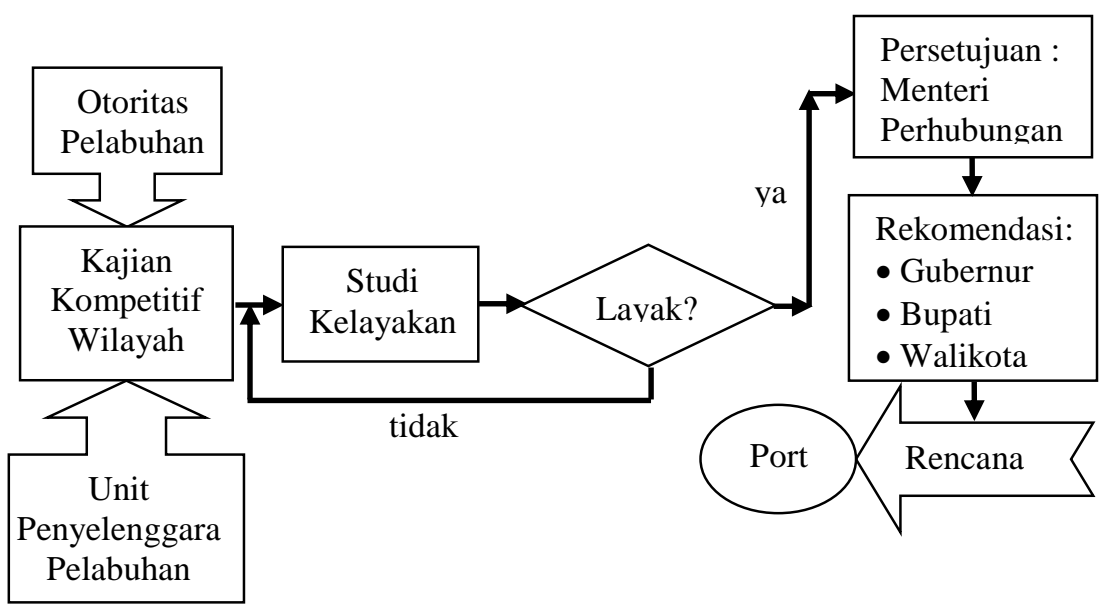

Sumber : D.A. Lasse, Dr, SH,MM, Manajemen Pelabuhan.

Prosedur mendapatkan persetujuan pemerintah untuk menetapkan lokasi pelabuhan berdasarkan UU 17/2008 Tentang Pelayaran menyatakan bahwa usulan pembangunan suatu pelabuhan laut atau pelabuhan sungai harus sesuai dengan rencana Induk Pelabuhan Nasionalyang ditetapkan pemerintah c.q Menteri Perhubungan untuk jangka waktu 20 (dua puluh) tahun. Rencana Induk Pelabuhan Nasional memuat (a) Kebijakan Nasional; (b) Rencana Lokasi dan Hierarki Pelabuhan ${ }^{7}$

Rencana Induk Pelabuhan Panjang berdasarkan Keputusan Menteri Perhubungan Nomor 32/2006 Tentang Rencana Induk Pelabuhan Panjang masih berpedoman pada UU 21/1992 Tentang Pelayaran, PP 69/2001 Tentang Kepelabuhanan dan KM 54/2002 Tentang Penyelenggaraan Pelabuhan Laut. sehingga Rencana Induk Pelabuhan Panjang harus dilakukan perubahan agar sesuai dengan UU 17/2008 Tentang Pelayaran, PP 61/2009 Tentang Kepelabuhanan dan PM 51/2015 Tentang penyelenggaraan pelabuhan Laut. Pada Pasal 351 Ayat (1) UU 17/2008 Tentang Pelayaran, Rencana Induk Pelabuhan serta DLKp dan DLKr yang telah ada sebelum UU tersebut harus selesai dievaluasi dan disesuaikan dengan UU Pelayaran tersebut paling lambat 2 (dua) tahun, sehingga penetapan peruntukkan lahan dalam rangka ikut serta peran swasta, Pemerintah Daerah dapat berpartisipasi sebagai BUP baru yang ikut melakukan kegiatan Pengusahaan.

\footnotetext{
${ }^{7}$ Lasse, D.A. (2014). Manajemen Kepelabuhanan. Jakarta: Rajawali Press, p. 61.
} 


\section{b. Penyediaan Lahan di Daratan dan di Perairan Pelabuhan}

Pasal 83 Ayat (1) huruf a UU 17/2008 Tentang Pelayaran menjelaskan bahwa Penyediaan lahan di daratan pelabuhan dilakukan oleh Otoritas Pelabuhan atau Unit Penyelenggara Pelabuhan kepada Badan Usaha Pelabuhan (BUP) yang peruntukkannya untuk kegiatan pengusahaan di lingkup area pelabuhan. Sedangkan penyediaan lahan di perairan dilakukan sesuai kebutuhan operasional pelabuhan dan untuk menjamin keselamatan pelayaran.

Pada Pasal 11 Ayat (3) dan (4) PM Perhubungan 51/2015 Tentang Penyelenggaraan Pelabuhan Laut menjelaskan bahwa :

(3) Dalam hal diatas lahan yang diperlukan untuk Pelabuhan terdpaat hak atas tanah, penyediaannya dilakukan dengan cara Pengadaan Tanah.

(4)Dalam hal penyediaan tanah dilakukan oleh BUP maka Hak atas tanah merupakan hak pengelolaan Penyelenggara Pelabuhan yang nilainya diperhitungkan dalam perjanjian konsesi

Pada pasal tersebut menjelaskan bahwa mekanisme penyediaan lahan daratan dapat dilakukan oleh Otoritas Pelabuhan dengan cara Pengadaan Tanah, ataupun dengan penyediaan dilakukan oleh BUP yang kemuadian Hak atas tanah tersebut menjadi Hak Pengelolaan Penyelenggara Pelabuhan.

Penyediaan Tanah yang dilakukan oleh Otoritas Pelabuhan melalui mekanisme Pengadaan tanah berdasarkan Undang-Undang Nomor 2 Tahun 2012 Tentang Pengadaan Tanah bagi pembangunan untuk kepentingan umum, yaitu dengan cara menyediakan tanah dengan cara memberi ganti kerugian yang layak dan adil kepada pihak yang berhak. Pelabuhan menjadi salah objek yang menjadi lingkup dalam Undang-Undang tersebut sehingga. Mekanisme pengadaan tanah harus melalui beberapa tahapan, yaitu: Perencanaan, Persiapan, Pelaksanaan, Penyerahan hasil. Proses pengadaan tanah pelabuhan harus memperhatikan Rencana Induk Pelabuhan.

Penyediaan tanah yang dilakukan oleh BUP, sesuai dengan Pasal 30 Ayat (5) PM 51/2015 Tentang Penyelenggaraan Pelabuhan Laut, yaitu dalam izin usaha BUP harus memenuhi persyaratan teknis yang salah satunya harus memiliki lahan. lahan daratan/ tanah yang dimiliki BUP kemudian menjadi Hak Pengelolaan Penyelenggara Pelabuhan yang nilai lahan tersebut menjadi komponen yang diperhitungkan dalam pemberian konsesi pada BUP tersebut.

Penyediaan lahan yang dilakukan oleh Otoritas Pelabuhan dan BUP yang kemudian menjadi Hak Pengelolaan dari Otoritas Pelabuhan harus memperhatikan Rencana Induk Pelabuhan pada pelabuhan tersebut. Pada pembahasan sebelumnya, terkait pengadaan tanah dalam rangka pengelolaan lahan kepelabuhanan, Otoritas Pelabuhan masih terkendala dengan anggaran 
dari pemerintah. Sehingga Otoritas Pelabuhan tidak dapat melakukan penyusunan Rencana Induk Pelabuhan sesuai yang diamanatkan oleh UU 17/2008 Tentang Pelayaran sehingga lahan-lahan yang dapat diperuntukkan untuk pelabuhan yang akan dikelola oleh BUP baru belum ada kajian terhadap pedoman dalam penetapan lokasi, pembangunan, pengoperasian, pengembangan Pelabuhan. Padahal Rencana Induk Pelabuhan dapat ditinjau kembali 1 (satu) kali atau lebih dalam waktu 5 (lima) Tahun. pada Pasal 71 ayat (5) dan (6) UU 17/2008 Tentang Pelayaran :

(5) Rencana Induk Pelabuhan Nasional sebagaimana dimaksud pada ayat (4) dapat ditinjau kembali 1 (satu) kali dalam 5 (lima) tahun.

(6) Dalam hal terjadi perubahan kondisi lingkungan strategis akibat bencana yang ditetapkan dengan ketentuan peraturan perundang-undangan Rencana Induk Pelabuhan Nasional dapat ditinjau kembali lebih dari 1 (satu) kali dalam 5 (lima) tahun.

\section{c. Pengaturan dan Pengawasan Penggunaan Lahan Daratan dan Perairan Pelabuhan serta DLKp dan DLKr Pelabuhan}

Pasal 84 UU 17/2008 tentang Pelayaran Jo. Pasal 66 PP 61/2009 Tentang Kepelabuhanan Jo. Pasal 24 PM Perhubungan 51/2015 Tentang Penyelenggaraan Pelabuhan Laut menetapkan bahwa dalam menjalankan tugasnya, Otoritas Pelabuhan melakukan pengaturan dan pengawasan penggunaan lahan daratan dan perairan serta DLKp dan DLKR Pelabuhan. Hal tersebut merupakan kewenangan dari tugas Otoritas Pelabuhan dalam menyusun Rencana Induk Pelabuhan serta penyediaan lahan daratan dan perairan pelabuhan. Pada Pasal 19 PM Perhubungan 36/2012 Tentang Organisasi dan Tata Kerja Kantor Kesyahbandaran dan Otoritas Pelabuhan, bahwa yang melakukan pengaturan dan pengawasan penggunaan lahan daratan dan perairan serta DLKp dan DLKR Pelabuhan dibawah wewenang Bidang Lalu Lintas dan Angkutan Laut, dan Usaha Kepelabuhanan. Kegiatan mengatur dan mengawasi penggunaan lahan daratan dan perairan serta DLKp dan DLKr dilakukan dalam rangka terciptanya optimalisasi pemanfaatan lahan kepelabuhanan serta terciptanya keamanan dan kenyamanan di lingkungan pelabuhan.

Otoritas Pelabuhan yang merupakan tranformasi dan Administrator Pelabuhan dibawah Direktur Jenderal Perhubungan Laut yang semula tugasnya hanya di lingkup teknis keselamatan, ketertiban dan keamanan serta kelaiklautan $\mathrm{kapal}^{8}$, dengan diberikannya wewenang dalam pengaturan dan pengawasan penggunaan Lahan daratan dan Perairan serta DLKp dan

\footnotetext{
${ }^{8}$ Gurning, Raja Oloan Saut dan Budiyanto, Eko Hariyadi. Op. Cit., p. 8.
} 
DLKr Pelabuhan, maka aparat - aparat Otoritas Pelabuhan wajib menguasai ilmu bisnis Kepelabuhanan. karena dalam pengaturan dan pengawasan lahan pelabuhan, harus mencakup aspek-aspek bisnis serta tetap berpatokan pada Rencana Induk Pelabuhan. Pengaturan dan Pengawasan yang dilakukan Otoritas Pelabuhan pun meliputi penggunaan lahan oleh Pihak yang bekerja sama dengan BUP. Dengan mekanisme setiap kerjasama-kerjasama penggunaan lahan seperti BOT, BTO, BOWT harus mendapatkan rekomendasi dari Otoritas Pelabuhan. Hal ini dilaksanakan mengingat UU 17/2008 Tentang Pelayaran dalam sistem manajemen Pelabuhan di Indonesia menganut sistem Landlord Port dimana Kewenangan tertinggi ada pada Otoritas Pelabuhan.

\section{d. Pengusahaan lahan Pelabuhan}

Berdasarkan UU 17/2008 Tentang pelayaran, hakikatnya Otoritas Pelabuhan memiliki fungsi, tugas dan wewenang dalam aspek pemerintahan, tidak langsung pada aspek pengusahaan pelabuhan. Pengusahaan Pelabuhan menjadi tugas dan wewenang BUP setelah mendapat konsesi dari Otoritas Pelabuhan

Pada Pasal 83 Ayat (2), “ Selain tugas dan tanggung jawab sebagaimana dimaksud pada ayat (1) Otoritas Pelabuhan melaksanakan kegiatan penyediaan dan/atau pelayanan jasa kepelabuhanan yang diperlukan." oleh pengguna jasa yang belum disediakan oleh Badan Usaha Pelabuhan." Artinya Otoritas Pelabuhan melakukan kegiatan pengusahaan jasa kepelabuhanan bila BUP dalam suatu pelabuhan belum menyediakan jasa tersebut. Khususnya penyediaan yang berkaitan dengan penggunaan lahan di pelabuhan seperti :

1) Penyediaan dan/atau pelayanan jasa dermaga untuk bertambat.

2) Penyediaan dan/atau pelayanan jasa dermaga untuk pelaksanaan kegiatan bongkar muat barang dan peti kemas.

3) Penyediaan dan/atau pelayanan jasa gudang dan tempat penimbunan barang.

4) Penyediaan dan/atau pelayanan jasa terminal peti kemas, curah cair, curah kering, dan Ro-Ro.

5) Penyediaan dan/atau pelayanan jasa bongkar muat barang. 


\section{Kewenangan PT. Pelabuhan Indonesia II (Persero) Cabang Panjang dalam Pengelolaan Lahan Kepelabuhanan yang telah diusahakan kaitannya dengan keberadaan Otoritas Pelabuhan sebagai Regulator}

UU 17 Tahun 2008 Tentang Pelayaran sebagai bentuk reformasi peraturan Kepelabuhanan disusun dalam upaya untuk: ${ }^{9}$

a. Menghapus Monopoli

b. Menciptakan kesempatan yang lebih luas untuk investasi di sektor pelabuhan (Pihak Swasta dan Pemerintah Daerah).

c. Menciptakan kompetisi yang sehat dalam pelabuhan dan antar Pelabuhan.

d. Pemisahan yang jelas antara Regulator dan Operator dengan pembentukkan Otoritas Pelabuhan.

e. Mengakomodasi Otonomi Daerah.

Di dunia maritim, dari lingkup tugas dan tanggung jawabnya, Otoritas Pelabuhan di Indonesia dikategorikan sebagai Landlord port. Adapun pelayanan kepelabuhannya dikerjakan BUP yang mempersilakan partisipasi swasta. Otoritas Pelabuhan berperan layaknya seperti tuan tanah yang memberikan konsesi aset tidak bergerak berupa lahan dan bangunan untuk dipakai, dioperasikan, dan tidak dimiliki hingga suatu masa atau periode tertentu yang disepakati. Kemudian sebuah entitas pengelola ditunjuk atau disepakati mengusahakan aset yang ada dan melengkapi dengan sistem peralatan bongkar muat dan sistem informasi lainnya untuk mengoperasikan sebuah tipe jasa kepelabuhanan tertentu. Pemilik aset Kepelabuhanan di Indonesia berdasarkan ketentuan perundang-undangan dan berhak atas kompensasi atas dari aset yang dikonsesikannya dalam suatu prestasi tertentu berdasarkan fungsi profit, skala usaha, dan parameter lain yang telah disepakati bersama.

PT. Pelabuhan Indonesia II (Persero) Cabang Panjang (Pelindo Panjang) berdasarkan ketentuan UU 17/2008 Tentang Pelayaran saat ini adalah satu-satunya BUP yang konsisten melakukan kegiatan pengusahaan di Pelabuhan Panjang.

Pelindo Panjang sebagai BUP melakukan kegiatan pengusahaan kepelabuhanan yang berkaitan dengan penggunaan lahanberdasarkan Pasal 90 Ayat (3) UU 17/2008 Tentang Pelayaran meliputi :

a. Penyediaan dan/atau pelayanan jasa dermaga untuk bertambat.

b. Penyediaan dan/atau pelayanan jasa dermaga untuk pelaksanaan kegiatan bongkar muat barang dan peti kemas.

c. Penyediaan dan/atau pelayanan jasa gudang dan tempat penimbunan barang.

\footnotetext{
${ }^{9}$ Direktur Jenderal Perhubungan Laut. (2015). Sinkronisasi Pengaturan di Sektor Pelabuhan dalam Rangka Meningkatkan Daya Saing Indonesia di Dunia Internasional, Tanggal 24 Agustus 2015.
} 
d. Penyediaan dan/atau pelayanan jasa terminal peti kemas, curah cair, curah kering, dan Ro-Ro.

e. Penyediaan dan/atau pelayanan jasa bongkar muat barang.

Pelindo Panjang juga melakukan bekerja sama dengan Pihak Ketiga dalam pemanfaatan lahan di lingkungan kerja Pelabuhan berdasarkan berdasarkan Keputusan Direksi PT. Pelabuhan Indonesia II (Persero) Nomor : HK.56/6/18/PI.II-13 Tanggal Tentang Pedoman Pola Kerjasama pemanfaatan bagian-bagian tanah Hak Pengelolaan (HPL) Pelabuhan di lingkungan PT. Pelabuhan Indonesia II (Persero) di mana salah satu dasar pertimbangan keputusannya adalah Undang-Undang Nomor 17 Tahun 2008 Tentang Pelayaran. Bentuk kerjasama yang dapat dilakukan dalam pemanfaatan HPL tanah Pelabuhan di Daerah Lingkungan Kerja (DLKr) Pelabuhan Panjang dengan mitra kerjasama berdasarkan Surat Keputusan Direksi tersebut adalah :

\section{a. Kerjasama Build, Operate, Transfer (BOT)}

Adalah kerjasama bangun, guna, serah diatas Tanah HPL Pelabuhan, dimana mitra kerjasama mendirikan bangunan dan/atau sarana dan fasilitasnya, kemudian dikelola oleh mitra kerjasama tersebut untuk jangka waktu tertentu yang selanjutnya Tanah HPL beserta bangunan dan/ atau sarana berikut fasilitasnya diserahkan kepada perusahaan setelah berakhirnya jangka waktu kerjasama yang telah disepakati.

\section{b. Kerjasama Build, Transfer, Operate (BTO)}

Adalah kerjasama bangun, serah guna diatas Tanah HPL Pelabuhan, dimana mitra kerjasama mendirikan bangunan dan/ atau sarana fasilitasnya, yang kemudian setelah selesai pembangunan maka mitra kerjasama akan menyerahkan Tanah HPL beserta bangunan dan/ atau sarana berikut fasilitasnya kepada perusahaan, yang selanjutnya Perusahaan mengoperasikan selama jangka waktu tertentu.

\section{c. Kerjasama Build, Own, Transfer (BowT)}

Adalah kerjasama bangun, miliki, serah diatas tanah Pelabuhan, dimana mitra kerjasama mendirikan bangunan dan/ atau sarana dan fasilitasnya, kemudian bangunan dan/ atau sarana dan fasilitasnya dimiliki oleh mitra kerjasama tersebut untuk jangka waktu tertentu yang selanjutnya Tanah HPL beserta bangunan dan/ atau sarana berikut fasilitasnya diserahkan kepada perusahaan setelah berakhirnya jangka waktu kerjasama yang telah disepakati. 


\section{d. Kerjasama Operasi (KSO)}

Kerjasama Operasi adalah kerjasama dengan prinsip bagi hasil yang saling menguntungkan antara perusahaan dengan mitra kerjasama, dimana perusahaan ikut terlibat dalam manajemen pengelolaan.

\section{e. Kerjasama Usaha (KSU)}

Kerjasama Usaha adalah kerjasama dengan prinsip bagi hasil yang saling menguntungkan antara perusahaan dengan mitra kerjasama dimana perusahaan tidak ikut terlibat dalam manajemen pengelolaan. Lima bentuk kerjasama pemanfaatan lahan HPL oleh mitra dituangkan dalam Perjanjian Kerjasama yang minimal memuat lingkup perjanjian, hak kewajiban, waktu perjanjian, dan biaya perjanjian. meliputi :

Lingkup Pengelolaan Lahan Kepelabuhan dalam penulisan ini

a. penyusunan Rencana Induk Pelabuhan serta Daerah Lingkungan Kerja dan Daerah Lingkungan Kepentingan pelabuhan.

b. Penyediaan lahan di daratan dan di perairan Pelabuhan.

c. Pengaturan dan Pengawasan penggunaan lahan daratan dan perairan pelabuhan.

d. Pengusahaan lahan Pelabuhan

Pada periode dimana UU 21/1992 Tentang Pelayaran berlaku, Pelindo secara keseluruhan memiliki wewenang dalam lingkup Pengelolaan lahan Kepelabuhanan namun kemudian digantikan oleh UU 17/2008 Tentang Pelayaran kewenangan tersebut menjadi wewenang Otoritas Pelabuhan.

Pemisahan peran Regulator dan Operator di Pelabuhan menjadikan Kewenangan Pengelolaan Lahan Kepelabuhan dibagi sesuai dengan Tugas, Kewajiban dan wewenangnya.

Tabel 1.

Pelaksanaan Pengelolaan Lahan Kepelabuhanan

\begin{tabular}{|c|c|c|c|}
\hline No & Dasar & $\begin{array}{l}\text { Pemegang } \\
\text { Wewenang }\end{array}$ & $\begin{array}{c}\text { Lingkup Pengelolaan Lahan } \\
\text { Kepelabuhanan }\end{array}$ \\
\hline 1. & $\begin{array}{l}\text { UU 21/1992 } \\
\text { tentang } \\
\text { Pelayaran }\end{array}$ & $\begin{array}{l}\text { Penyelenggara } \\
\text { Pelabuhan Umum } \\
\text { / Pelindo }\end{array}$ & 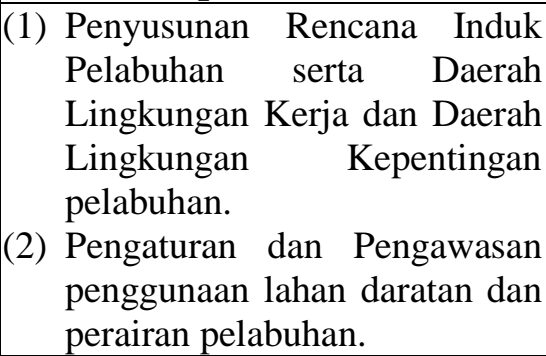 \\
\hline
\end{tabular}




\begin{tabular}{|c|c|c|c|}
\hline & & & (3) Pengusahaan lahan Pelabuhan \\
\hline 2. & $\begin{array}{l}\text { UU 17/2008 } \\
\text { Tentang } \\
\text { Pelayaran }\end{array}$ & $\begin{array}{l}\text { Regulator } \\
\text { Otoritas } \\
\text { Pelabuhan }\end{array}$ & $\begin{array}{l}\text { / (1) Penyusunan Rencana Induk } \\
\text { Pelabuhan serta Daerah } \\
\text { Lingkungan Kerja dan Daerah } \\
\text { Lingkungan Kepentingan } \\
\text { pelabuhan. } \\
\text { (2) Penyediaan lahan di daratan } \\
\text { dan di perairan Pelabuhan. } \\
\text { (3) Pengaturan dan Pengawasan } \\
\text { penggunaan lahan daratan dan } \\
\text { perairan pelabuhan. }\end{array}$ \\
\hline 3. & $\begin{array}{l}\text { UU 17/2008 } \\
\text { Tentang } \\
\text { Pelayaran }\end{array}$ & Operator / BUP & (1) Pengusahaan lahan Pelabuhan \\
\hline
\end{tabular}

Perumusan Rencana Induk Pelabuhan Panjang yang ditetapkan pada Keputusan Menteri Perhubungan Nomor 32/2006 Tentang Rencana Induk Pelabuhan Panjang. Perumusan yang meliputi kajian tentang rencana jangka pendek, jangka menengah dan jangka panjang serta proses perizinin ke berbagai instansi seperti Pemerintah Kota, Pemerintah Provinsi, serta ke Dinas Perhubungan sampai pengajuan ke Menteri Perhubungan pada saat itu adalah Pelindo Panjang yang pada saat itu sebagai Penyelenggara Pelabuhan yang tugasnya sebagai Operator merangkap sebagai Regulator. Sehingga bila pada ketentuan sekarang Perumusan Rencana Induk pelabuhan menjadi tugas dan wewenang Otoritas Pelabuhan, hal ini harus dijalankan mengingan regulator saat ini adalah Otoritas Pelabuhan.

Penyediaan lahan yang menjadi wewenang Otoritas Pelabuhan merupakan implikasi dari legalisasi peran serta swasta dan Pemerintah Daerah dalam melaksanakan kegiatan Pengusahaan Pelabuhan. Penyediaan lahan yang dimaksud ada penyediaan lahan oleh Otoritas Pelabuhan kepada Badan Usaha Pelabuhan yang baru dibentuk untuk melakukan kegiatan pengusahaan. Lahan yang disediakan oleh Otoritas Pelabuhan kepada BUP menjadi salah satu yang diperhitungkan dalam konsesi.

Artinya Pelindo pada saat sebelum UU 17/2008 tentang Pelayaran tidak melalukan penyediaan lahan daratan dan perairan. Karena sebelum UU 17/2008 Tentang Kepelabuhanan, karena hanya Pelindo sebagai BUP yang melakukan pengusahaan jasa Kepelabuhanan dan merangkap sebagai wakil pemerintah sebagai regulator. Sehingga sama seperti tugas dan wewenang Penyusunan Rencana Induk Pelabuhan dan Pengawasan Penggunaan lahan, Penyediaan lahan dan Pengawasan Penggunaannya menjadi tugas Regulator 
Pelabuhan. Siapapun yang ditunjuk oleh pemerintah untuk menjadi Regulator.

Dalam Kegiatan Pengusahaan jasa Kepelabuhanan oleh Pelindo Panjang yang menggunakan lahan Kepelabuhanan, tetap dilaksanakan oleh Pelindo Panjang. dasar kegiatan Pengusahaan lahan Kepelabuhanan tetap dilakukan oleh Pelindo Panjang ada pada Pasal 344 Ayat (3) UU 17/2008 Tentang Pelayaran : "Kegiatan pengusahaan di pelabuhan yang telah diselenggarakan oleh Badan Usaha Milik Negara tetap diselenggarakan oleh Badan Usaha Milik Negara dimaksud." Penjelasan pasal tersebut dalam UU tersebut adalah :

"Yang dimaksud dengan "tetap diselenggarakan oleh Badan Usaha Milik Negara" adalah Badan Usaha Milik Negara yang didirikan berdasarkan Peraturan Pemerintah Nomor 56 Tahun 1991, Peraturan Pemerintah Nomor 57 Tahun 1991, Peraturan Pemerintah Nomor 58 Tahun 1991, dan Peraturan Pemerintah Nomor 59 Tahun 1991, tetap menyelenggarakan kegiatan usaha di pelabuhan yang meliputi:

a. kegiatan yang diatur dalam Pasal 90 ayat (1), ayat (2), ayat (3), dan ayat (4) Undang-Undang ini.

b. Penyediaan kolam pelabuhan sesuai dengan peruntukannya berdasarkan pelimpahan dari Pemerintah dan ketentuan peraturan perundangundangan.

c. Pelayanan jasa pemanduan berdasarkan pelimpahan dari Pemerintah dan ketentuan peraturan perundang-undangan.

d. Penyediaan dan pengusahaan tanah sesuai kebutuhan berdasarkan pelimpahan dari Pemerintah dan ketentuan peraturan perundangundangan di bidang pertanahan.

Pasal 344 Ayat (3) UU 17/2008 Tentang Pelayaran yang mengatur secara tegas bahwa penyelenggaraan kegiatan pengusahaan pelabuhan yang telah diselenggarakan oleh BUMN Kepelabuhanan tetap diselenggarakan oleh BUMN Kepelabuhanan tersebut. Ketentuan dimaksud telah memberikan pelimpahan secara langsung (konsesi) kepada BUMN Kepelabuhanan PT. Pelabuhan Indonesia I, II, III, dan IV dalam penyelenggaraan kegiatan pengusahaan pelabuhan. Pasal tersebut merupakan penegasan dari concession by law (konsesi yang diberikan langsung oleh Undang-Undang $)^{10}$

Pasal 92 UU 17/2008 Tentang Pelayaran yang menjelaskan bahwa Kegiatan penyediaan dan/atau pelayanan yang dilaksanakan oleh BUP berdasarkan konsesi atau bentuk lainnya dari Otoritas Pelabuhan, yang dituangkan dalam perjanjian, hanya diperuntukkan kepada BUP yang baru dibentuk setelah UU 17/2008 Tentang Pelayaran lahir. Konsesi menurut UU

${ }^{10}$ WHITE BOOK IPC, p. 17. 
17/2008 Tentang Pelayaran adalah pemberian hak oleh Penyelenggara Pelabuhan kepada Badan Usaha Pelabuhan untuk melakukan kegiatan penyediaan dan/atau pelayanan jasa kepelabuhanan tertentu dalam jangka waktu tertentu dan kompensasi tertentu.

Pengaturan tentang konsesi dimuat pada PM 15/2015 Tentang Konsesi dan bentuk kerjasama lainnya antara Pemerintah dengan Badan Usaha Pelabuhan di Bidang Kepelabuhanan. pada Pasal 28 Ayat (1) Peraturan Menteri Perhubungan tersebut, memuat tentang konsesi dapat diberikan kepada pengelolaan fasilitas yang telah dibangun/ dikembangkan oleh BUP Kepelabuhanan (Pelindo), kemudian pada Pasal 28 Ayat (2), konsesi diberikan melalui mekanisme penunjukkan/ penugasan langsung. Dan pada Ayat (3) dan (4) menjelaskan bahwa :

(3) Dalam hal masa konsesi telah berakhir, fasilitas pelabuhan hasil konsesi pada ayat (1) beralih atau diserahkan kepada Penyelenggara Pelabuhan

(4) Lahan sebagaimana dimaksud pada ayat (3) diserahkan hak nya kepada Penyelenggara Pelabuhan sebagai Hak Pengelolaan sebelum perjanjian konsesi ditandatangani. Dan terhadap Badan Usaha Pelabuhan akan diberikan Hak diatas Hak Pengelolaan yang dimiliki Penyelenggara Pelabuhan sesuai dengan ketentuan perundang-undangan.

Berdasarkan peraturan Perundang-Undangannya, teknis setelah konsesi diberikan oleh Otoritas Pelabuhan kepada Pelindo terkait pengusahaan fasilitas Pelabuhan termasuk lahan didalamnya, harus menyerahkan seluruh lahan yang telah memiliki Hak Pengelolaan atas nama Pelindo. Kemudian besaran pendapatan konsesi yang sejatinya adalah pendapatan negara dan jangka waktu konsesi diperhitungkan berdasarkan total aset yang dimiliki oleh Pelindo. Dan akibat dari berakhirnya konsesi, seluruh fasilitas termasuk lahan menjadi Hak Pengelolaan Penyelenggara Pelabuhan atau Otoritas Pelabuhan.

Sementara itu, Penasehat SPPI Armen Amir mengatakan regulasi Kementerian Perhubungan yang ada saat ini dan yang akan diterbitkan tidak mencerminkan semangat sebagaimana yang diatur dalam Pasal 344 ayat (3) UU Nomor 17 tahun 2008 dan Pasal 165 ayat (3) PP Nomor 61 tahun 2009.

Ketentuan tersebut tidak mencerminkan maksud dan penjelasan dari Pasal 344 Ayat (3) UU 17/2008 Tentang Pelayaran dan Pasal 165 Ayat (3) PP 61/2009 Tentang Kepelabuhanan, dalam pasal tersebut telah memberikan kepastian secara hukum tentang status hukum keberadaan BUMN Kepelabuhanan dalam pengusahaan kegiatan jasa kepelabuhanan. Sehingga tidak harus melalui konsesi.

Disamping itu juga, pada Peraturan Pemerintah 57/1991 Tentang Pengalihan bentuk Perusahaan Umum (PERUM) Pelabuhan II menjadi 
Perusahaan Perseroan (Persero), salah satu maksud dan tujuan dibentuknya Pelindo adalah "Menyelenggarakan usaha tanah untuk berbagai bangunan dan lapangan, sehubungan dengan kepentingan kelancaran angkutan laut dan industri”. Artinya Pelindo II didirikan dan dibentuk memang diperuntukkan untuk menyelenggarakan pengusahaan pelabuhan sesuai pada PP 57/1991 dimana salah satunya adalah usaha tanah untuk berbagai bangunan dan lapangan, sehubungan dengan kepentingan kelancaran angkutan laut dan industri.

Hal ini juga diperkuat dengan tidak adanya transfer of assets dari Pelindo kepada Regulator. Hal ini sesuai dengan maksud dan tujuan pendirian BUMN sebagai Kekayaan Negara yang dipisahkan. Kekayaan Negara yang dipisahkan menurut UU 19/2003 Tentang Badan Usaha Milik Negara adalah kekayaan negara yang berasal dari Anggaran Pendapatan dan Belanja Negara (APBN) untuk dijadikan penyertaan modal negara pada Persero dan/atau Perum serta perseroan terbatas lainnya.

Ketentuan tersebut juga tidak sesuai dengan cara peralihan Hak Pengelolaan dari Pelindo ke Otoritas Pelabuhan. Boedi Harsono menyatakan bahwa Hak menguasai dari negara tidak dapat dipindahkan kepada pihak lain, tetapi pelaksanaannya dapat dilimpahkan kepada Pemerintah Daerah dan masyarakat hukum adat, sepanjang hal itu diperlukan dan tidak bertentangan dengan kepentingan nasional, sebagai tugas pembantuan bukan otonomi. ${ }^{11}$ Konsekuensi logisnya , HPL pun tidak bisa dipindahkan kepada pihak lain, kecuali hak-hak atas tanah yang lahir dari HPL tersebut. Boedi Harsono menegaskan, HPL didaftar dan diterbitkan sertipikat sebagai tanah bukti haknya, tetapi "gempilan" HMN tidak dapat dipindahtangankan ${ }^{12}$. Artinya , HPL tidak dapat berpindah "hak" nya kepada subjek lainnya melalui perbuatan hukum pemindahan hak (seperti jual-beli). Sebagaimana teori hukum pada umumnya, tindakan pemindahan hak hanya dapat dilakukan oleh suatu subjek hukum terhadap objek hukum yang dipunyai secara privat pula. Oleh karena hubungan hukum antara subjek dengan objek dalam HPL lebih bersifat publik, maka perbuatan hukum pemindahan hak (memindahkan hak secara langsung kepada subjek hukum yang lain) tidak diperkenankan secara hukum. Kalau ada maksud untuk mengakhiri hubungan hukum HPL antara dari subjek hukumnya kepada subjek hukum lain, maksud itu hanya dimungkinkan melalui pelepasan hak.

Maria S.W Sumardjono menegaskan bahwa tanah HPL tidak dapat diperjual-belikan/ dialihkan, tetapi dapat dilepaskan (kembali kepada Negara) untuk kemudian diberikan kepada pihak lain dengan sesuatu hak

11 Harsono, Boedi. (2008). Hukum Agraria Indonesia Sejarah Pembentukkan UndangUndang Pokok Agraria, Isi dan Pelaksanaannya. Jakarta: Djambatan, p. 277-278.

${ }^{12}$ Ibid. 
sesuai peraturan perundang-undangan yang berlaku. ${ }^{13}$ Penegasan "pelepasan Hak' sebagai pranata hukum hukum peralihan HPL ada sikap konsisten pada karakter publik dari HPL yang pada hakikatnya tidak bisa dipindahkan. Kalau karena kebutuhan tertentu akan dipindahkan kepada subjek hukum yang lain, maka prosedur hukum yang ditempuh harus terlebih dahulu mengembalikan penguasaan hukum tanah itu kepada negara. Setelah itu baru dilakukan pemberian HPL yang baru kepada subjek hukum yang baru pula. ${ }^{14}$

Sebagai perbandingan bila Pelindo Panjang dalam pelaksanaan Kegiatan Pengusahaan lahan Kepelabuhanan tidak melalui Konsesi dan melalui pemberian konsesi dari Otoritas Pelabuhan :

Tabel 2.

Perbandingan Pelaksanaan Kegiatan Pengelolaan Lahan Kepelabuhaan oleh Pelindo Panjang Konsesi Tanda

\begin{tabular}{|c|c|c|}
\hline No & $\begin{array}{l}\text { Tanpa Konsesi dari Otoritas } \\
\text { Pelabuhan }\end{array}$ & $\begin{array}{l}\text { Setelah mendapat Konsesi dari } \\
\text { Otoritas Pelabuhan }\end{array}$ \\
\hline 1. & $\begin{array}{lcc}\text { Pelindo } & \text { Panjang } & \text { tidak } \\
\text { membayar kompensasi } & 2,5 \% \\
\text { dari pendapatan kotor/ } & \text { bruto } \\
\text { kepada Otoritas Pelabuhan } & \end{array}$ & $\begin{array}{l}\text { Pelindo Panjang } \\
\text { kompensasi } 2,5 \% \text { dari pendapatan } \\
\text { kotor/ bruto kepada Otoritas } \\
\text { Pelabuhan }\end{array}$ \\
\hline 2. & $\begin{array}{l}\text { Dalam bermitra dengan Pihak } \\
\text { Lain dalam pemanfaatan bagian } \\
\text { lahan HPL, tidak perlu } \\
\text { mendapat rekomendasi dari } \\
\text { Otoritas Pelabuhan }\end{array}$ & $\begin{array}{l}\text { Dalam bermitra dengan Pihak Lain } \\
\text { dalam pemanfaatan bagian lahan } \\
\text { HPL, harus setelah mendapat } \\
\text { rekomendasi dari Otoritas } \\
\text { Pelabuhan }\end{array}$ \\
\hline 3. & $\begin{array}{l}\text { Pembayaran ke Negara hanya } \\
\text { berupa Deviden }\end{array}$ & $\begin{array}{l}\text { Pembayaran ke Negara Deviden } \\
\text { dan Konsesi }\end{array}$ \\
\hline
\end{tabular}

Sumber : Undang-Undang 17 Tahun 2008 Tentang Pelayaran \& Perjanjian tentang Kegiatan Pengusahaan di Pelabuhan yang diusahakan oleh PT. Pelabuhan Indonesia II (Persero)

Dampak dari Pengusahaan Lahan Pelabuhan yang telah diusahakan oleh Pelindo Panjang apabila melalui konsesi berpengaruh pada pendapatan Pelindo Panjang sebagai BUMN yang memiliki orientasi pada Pendapatan. Pelindo Panjang harus menyetorkan biaya konsesi kepada Otoritas Pelabuhan minimal 2,5\% dari pendapatan bruto. Selain itu juga, lahan yang telah ditetapkan sebagai aktiva tetap milik Pelindo Panjang harus diserahkan

\footnotetext{
${ }^{13}$ Sumardjono, Maria S.W. (2008). Tanah dalam Perspektif Hak Ekonomi Sosial dan Budaya. Jakarta: Penerbit Kompas, p. 58.

${ }^{14}$ Hutagalung, Arie Sukanti dan Sitorus, Oloan. (2011). Seputar Hak Pengelolaan. STPN Press, p. 53.
} 
seluruhnya kepada otoritas Pelabuhan. Hal ini sesuai dengan Pasal 86 UU 17/2008 Tentang Pelayaran. Padahal, ketentuan tersebut diperuntukkan untuk BUP yang baru dibentuk. Bukan untuk Pelindo Panjang.

\section{Penutup}

\section{Simpulan}

Lingkup Pengelolaan lahan Kepelabuhan berdasarkan UU 17/2008 Tentang Pelayaran yang menjadi wewenang Otoritas Pelabuhan meliputi Perumusan Rencana Induk Pelabuhan, Penyediaan Lahan Pelabuhan, Pengawasan Penggunaan Lahan daratan dan Perairan serta DLKp dan DLKr, dan Pengusahaan Lahan Pelabuhan. Khusus Pengusahaan lahan Pelabuhan, Otoritas berwenang apabila BUP belum menyediakan pengusahaan tersebut.

Kewenangan PT. Pelabuhan Indonesia II (Persero) Cabang Panjang dalam pengelolaan lahan Kepelabuhanan setelah lahirnya UU 17/2008 Tentang Pelayaran hanya sebatas pada pengusahaan lahan Kepelabuhanan tanpa melalui konsesi dari Otoritas Pelabuhan mengingat Pasal 344 Ayat (3) UU 17/2008 Tentang Pelayaran dan Pasal 165 Ayat (3) PP 61/2009 Tentang Kepelabuhanan, dalam pasal tersebut telah memberikan kepastian secara hukum tentang status hukum keberadaan BUMN Kepelabuhanan dalam pengusahaan kegiatan jasa kepelabuhanan

\section{Saran}

1. UU 17/2008 Tentang Pelayaran merupakan Undang-Undang yang merubah sistem Kepelabuhanan di Indonesia yang semula Operating Port, menjadi Landlord Port. Dan memisahkan fungsi Regulator dan Operator Pelabuhan. Sehingga Lingkup Pengelolaan Lahan Kepelabuhanan dilaksanakan oleh pihak-pihak yang berperan sebagai Regulator dan Operator; dan

2. Agar memberikan kepastian hukum dalam kepada pihak-pihak yang memiliki wewenang di lingkungan Kepelabuhanan dengan mengkaji pasal-pasal yang ada didalamnya agar tidak terjadi tumpang tindih dalam melaksanakan kewenangan Pengelolaan lahan Kepelabuhanan. Khususnya pemberian konsesi kepada Pelindo Panjang sebagai BUP tidak perlu dilakukan. 


\section{Daftar Pustaka}

\section{A. Buku}

Harsono, Boedi. (2008). Hukum Agraria Indonesia Sejarah Pembentukkan Undang-Undang Pokok Agraria, Isi dan Pelaksanaannya. Jakarta: Djambatan.

Hutagalung, Arie Sukanti dan Sitorus, Oloan. (2011). Seputar Hak Pengelolaan. STPN Press.

Karsafman, Tjetjep. (2004). Port and Shipping. Jakarta.

Lasse, D.A. (2014). Manajemen Kepelabuhanan. Jakarta: Rajawali Press.

Nuryanto. (2011). Implementasi Undang-Undang Pelayaran: Dapatkah Menghilangkan Monopoli Pelabuhan?. STIMART “AMNI”,

Oloan SG., Raja dan Haryadi B, Eko. (2007). Manajemen Bisnis Pelabuhan. APE Publishing.

Sumardjono, Maria S.W. (2008). Tanah dalam Perspektif Hak Ekonomi Sosial dan Budaya. Jakarta: Penerbit Kompas.

Tjetjep Karsafman. Ks. (2004), Port \& Shipping.

Triatmojo, Bambang. (1996). Pelabuhan. Yogyakarta: Beta Offset.

\section{B. Peraturan Perundang-Undangan}

Undang-Undang Nomor 19 Tahun 2003 Tentang Badan Usaha Milik Negara Peraturan Pemerintah Nomor 61 Tahun 2009 Tentang Kepelabuhanan

Peraturan Pemerintah nomor 64 Tahun 2015 Tentang Perubahan atas Peraturan Pemerintah nomor 61 Tahun 2009 Tentang Kepelabuhanan

Peraturan Menteri Perhubungan nomor 15 Tahun 2015 Tentang Konsesi dan bentuk Kerjasama lainnya antara Pemerintah dengan Badan Usaha Pelabuhan di bidang Kepelabuhanan

Peraturan Menteri Perhubungan nomor 166 Tahun 2015 Tentang Perubahan atas Peraturan Menteri Perhubungan nomor 15 Tahun 2015 Tentang Konsesi dan bentuk Kerjasama lainnya antara Pemerintah dengan Badan Usaha Pelabuhan di bidang Kepelabuhanan

Surat Keputusan Bersama Menteri Dalam Negeri dan Menteri Perhubungan Nomor : 63 Tahun 1987 / Nomor : KM 154 / AL 106 / PHB-87 Tentang Batas-batas Daerah Lingkungan Kerja dan Daerah Lingkungan Kepentingan

\section{Lain-lain}

Direktur Jenderal Perhubungan Laut. (2015). Sinkronisasi Pengaturan di Sektor Pelabuhan dalam Rangka Meningkatkan Daya Saing Indonesia di Dunia Internasional, Tanggal 24 Agustus 2015.

Information Booklet PT. Pelabuhan Indonesia II (Persero) Cabang Panjang WHITE BOOK IPC 